UDC 621.39

\title{
AN APPROACH TO RESOURCE ALLOCATION FOR FUTURE WLAN
}

\author{
Andriy Luntovskyy \\ BA Dresden Univ. of Coop. Education Saxon Academy of Studies Dresden, Germany \\ Mykhailo Klimash \\ Lviv National Technical University “Lviska Polytechnika” Lviv, Ukraine
}

\begin{abstract}
Background. Nowadays wireless and mobile communication is occupied with provision in general of IP-services and transmission of MM-content from one place to another, but tomorrow the new $5 \mathrm{G}$ will be able to control a wide range of objects in real time with only insignificant human intervention. IoT with multiple new attractive apps is created. An important new approach for resource allocation for future WLAN towards $5 \mathrm{G}$ has to be discussed within the work.

Objective. DIDO (Distributed Input Distributed Output) - a new technology aimed to provide flexible multiuser wireless LAN everywhere under international voting and conventions for the used frequencies amongst other mobile technologies towards 5G. DIDO is aimed to resource allocation for future wireless communication networks which can use the wide non-traditional frequencies spectra between $3 \mathrm{MHz}$ and $30 \mathrm{GHz}$ and independently with full bandwidth and higher data rate operate under the distances between $100 \mathrm{~m}$ and $1000 \mathrm{~km}$.

Methods. Analysis of all known publications devoted to the new generation of mobile communication 5G was done. The interoperability aspects of 5G to WLAN, BT, WSN and other micro- and pico- radio nets were discussed. A new approach to frequency resource allocation for future WLAN was examined.

Results. An overview is given as well as main research points of view for the future $5 \mathrm{G}$ of mobile radio networks by the IMT 2020 standard are examined. They include inter alia the technique DIDO (Distributed Input Distributed Output), a perspective resource allocation for future wireless communication networks. The technology should only augment the existing GERAN, UTRAN, SAE and IMS mobile radio infrastructure of previous generations 2G-4G with a flexible world-wide WLAN, which is operated under use of a data bases for available frequency bands and the Web-based content called DIDO Data Centers.

Conclusions. Efficient WLANs as well as DIDO must become a part of 5G systems. By the opinion of some leading companies like Rearden, Microsoft, Samsung, Huawei the method DIDO has to be used as a new resource allocation method for future WLANs.
\end{abstract}

Keywords: 5G; WLAN; DIDO; IoT; QoS; QoE (Quality of Experience).

\section{G Visions and Requirements}

Nowadays wireless and mobile communication is occupied with provision in general of IP-services and transmission of MM-content from one place to another, but tomorrow the new $5 \mathrm{G}$ will be able to control a wide range of objects in real time with only insignificant human intervention in the frame of IoT and other attractive apps. "The Internet will disappear in our senses and sensitivities" (E. Schmidt, ex-CEO of Google).

One of the most popular definitions for $5 \mathrm{G}$ as a new generation of mobile communication is as follows: "In evolutionary view it will be capable to support wireless WWW allowing highly flexible dynamic ad-hoc wireless networks; in revolutionary view, this intelligent technology is capable of interconnecting the entire world without limits" $[1,2]$. A comparison of the mobile network generations is given via Table I. The leading specialists from Deutsche Telekom, NTT DoCoMo,
Amtel, Telefonica, Vodafone, Ericsson, Samsung [3 - 5] generate urgently their visions and technical requirements for future generation mobile communication as well as new standard 5G/ IMT 2020. The Samsung mmWave Testbeds [3] (Oct. 2014) have shown:

1. 2GBit/s @ 110km/h /World's First 5G Data Transmission at Highway Speeds

2. Record-breaking $1.2 \mathrm{GBit} / \mathrm{s}$ data transmission at over $100 \mathrm{~km} / \mathrm{h}$.

3. $7.5 \mathrm{GBit} / \mathrm{s}$ in stationary conditions using $28 \mathrm{GHz}$ spectrum.

The main 5G requirements are as follows [1-5]:

1. Use of existing 4G-insfrastructure with augmentation via flexible WLAN conform communication everywhere under international voting and conventions;

2. To medium term obtaining of $\mathrm{DR}=10 \mathrm{GBit} / \mathrm{s}$; this DR corresponds to up-to-date needs to MMcontent download; 
3. Tiny latencies, real time, inter-operability, services without human intervention;

4. Wide use of available frequency bands: mm-Band $\mathrm{F}=30$ up to $300 \mathrm{GHz}$ (partially and questionable);

5. Inter-operability with further mobile and wireless radio networks.

TABLE I. MOBILE GENERATION COMPARISON (SOURCE: HTTP://WWW.ELEKTRONIK-KOMPENDIUM.DE)

\begin{tabular}{|c|c|c|c|}
\hline Generation & $\begin{array}{l}\text { Radio } \\
\text { technology }\end{array}$ & Transfer type & Data rate \\
\hline $1 G$ & AMPS & $\begin{array}{l}\text { analog, circuit } \\
\text { switching, obsolete! }\end{array}$ & - \\
\hline $2 G$ & GSM & digital, circuit switching & $9,6 \mathrm{kBit} / \mathrm{s}$ \\
\hline 2.5G & HSCSD & digital, circuit switching & $57,6 \mathrm{kBit} / \mathrm{s}$ \\
\hline 2.5G & GPRS & digital, packet switching & $115 \mathrm{kBit} / \mathrm{s}$ \\
\hline $2.75 G$ & EDGE & digital, packet switching & $236 \mathrm{kBit} / \mathrm{s}$ \\
\hline 3G & $\begin{array}{l}\text { UMTS/ UTRA } \\
\text { FDD }\end{array}$ & $\begin{array}{l}\text { digital, mostly packet } \\
\text { switching }\end{array}$ & $384 \mathrm{kBit} / \mathrm{s}$ \\
\hline $3 G$ & $\begin{array}{l}\text { UMTS/ UTRA } \\
\text { TDD }\end{array}$ & $\begin{array}{l}\text { digital, mostly packet } \\
\text { switching }\end{array}$ & $2 \mathrm{Mbit} / \mathrm{s}$ \\
\hline 3.5G & $\begin{array}{l}\text { HSPA } \\
\text { (HSDPA, } \\
\text { HSUPA) }\end{array}$ & digital, packet switching & 14,4 MBit/s \\
\hline 3.9G & LTE & digital, packet switching & $150 \mathrm{MBit} / \mathrm{s}$ \\
\hline $4 G$ & LTE Advanced & $\begin{array}{lr}\text { digital, } & \text { packet } \\
\text { switching, } & \text { actual } \\
\text { standard } & \end{array}$ & $1 \mathrm{GBit} / \mathrm{s}$ \\
\hline 5G & IMT2020 & digital, packet switching & $10 \ldots 100 \mathrm{GBit} / \mathrm{s}$ \\
\hline
\end{tabular}

The advanced antenna technique MIMO was already deployed in diversity network technologies like WiMAX 802.16a/d/e/m, WLAN 802.11n/ac/ad, LTE etc. MIMOantennas allows nowadays communication with $\mathrm{NTx}=16$ transmitting and $\mathrm{NRx}=16$ receiving antennas. Thus, also downlink with $\mathrm{DR}=10 \mathrm{GBit} / \mathrm{s}$ and above is possible. This $\mathrm{DR}=10 \mathrm{GBit} / \mathrm{s}$ is about $\mathrm{x} 100$ in contrast to $\mathrm{DR}=100 \mathrm{MBit} / \mathrm{s}$ (current status of peak data rate of LTE). The standard IMT 2020 / 5G the wide use of 3D-Arrays for Multiple Input Multiple Output (MIMO up to $16 \times 16 \times 16)$ is foreseen $[6-10]$.

The prognosis is as follows: in 2020 up to 50 milliards devices will be IPv6-driven working, partially with $5 \mathrm{G}$. So, for instance, the priority $5 \mathrm{G}$ directions (Table II) for such company as Ericsson are as follows [1-5]:

1. Digital Economy;

2. Remote Machine Control;

3. Smart Grid / Smart Metering;

4. Internet Touch Technologies;

5. Smart Cities;

6. and IoT (Internet of Things) [1, 4, 10-13] .
The recent $5 \mathrm{G}$ forums are as follows:

1. 5G PPP (5G Infrastructure Public-Private Partnership);

2. METIS (Mobile and wireless communications Enablers for Twenty-twenty (2020) Information Society).

The architecture components of 5G Mobile Network are shown in Fig. 1. In the given 5G scenario the multimodal access and SDN core are represented. Based on the representation the $5 \mathrm{G}$ construction points of gratitude are considered as follows. The wide use of $\mathrm{Wi}$ Fi/WLAN is foreseen. In general, the prominent companies make also the preparations to further 5G/ WLAN development. The company Microsoft intends it soon, to provide the access to the 10 million WLAN hotspots. Through its Internet telephony subsidiary Skype Microsoft offers already the Wi-Fi access to about two million hotspots world-wide. Under the label "Microsoft WLAN" the access rights will be granted to the Office and Skype customers [13].

TABLE II. 5G SERVICE VISIONS

\begin{tabular}{|c|c|c|c|}
\hline \multicolumn{4}{|c|}{ Visions } \\
\hline $\begin{array}{l}\text { Everything } \\
\text { on Cloud }\end{array}$ & $\begin{array}{l}\text { Immersive } \\
\text { Experience }\end{array}$ & $\begin{array}{l}\text { Ubiquitous } \\
\text { Connectivity }\end{array}$ & Telepresence \\
\hline $\begin{array}{l}\text { Desktop- } \\
\text { like } \\
\text { experience } \\
\text { on the go }\end{array}$ & $\begin{array}{l}\text { Lifelike media } \\
\text { everywhere }\end{array}$ & $\begin{array}{l}\text { An intelligent } \\
\text { Web of } \\
\text { connected things }\end{array}$ & $\begin{array}{l}\text { Real-time } \\
\text { remote control }\end{array}$ \\
\hline
\end{tabular}

Use of SDN for software implementation of provider core in practice for $5 \mathrm{G}$ networks enables to enterprises and providers to receive vendor-independent functions for management and control of network components and services from any type of unified providing center, which will greatly simplify their operation. The use of SDN as part of the 5G/ IMT 2020 is a determined position [1, 3, 10]. Despite improving advanced RAT (Radio Access Technology) and RLAN (Radio LAN) as well as use of new database system for frequency assignment DIDO (Distributed Input Distributed Output), use of infrastructure based on existing systems 4G/ SAE, 3G/ UTRAN, 2G/ GERAN, an important role play core virtualization services, carried out via SDN. Using SDN for software implementation of provider core in practice for $5 \mathrm{G}$ networks enable to enterprises and providers to receive vendor-independent functions for management and control of network components and services from any type of unified providing center, which will greatly simplify their operation. Advanced adaptive modulation techniques for beyond $4 \mathrm{G}$ cellular and wireless communication are used [14]. They are aimed to more dense and robust covering of the geographic areas as well 
as the increasing of the QoE (Quality of Experience) in $5 \mathrm{G}$ nets.

As another promising application for 5G (IMT2020) networks the establishment of IoT (Internet of Things) [10-13] is considered which is based on inter-operability of different physical types of radio networks as well as virtualization technology for the core services to interact with each other and with the external environment (6LoWPAN, SDN). The features of future 5G (IMT2020) are as follows (Table II). The following scenarios of 5G deployment regarding to IoT/ Ubiqitous Computing became realistic [1-5]:

- Smart Home, Smart Manufacturing, Smart Health;

- Smart Retail, Smart Transportation, Smart City.

- Remote Surgery, Hazardous Work, and Remote Driving.

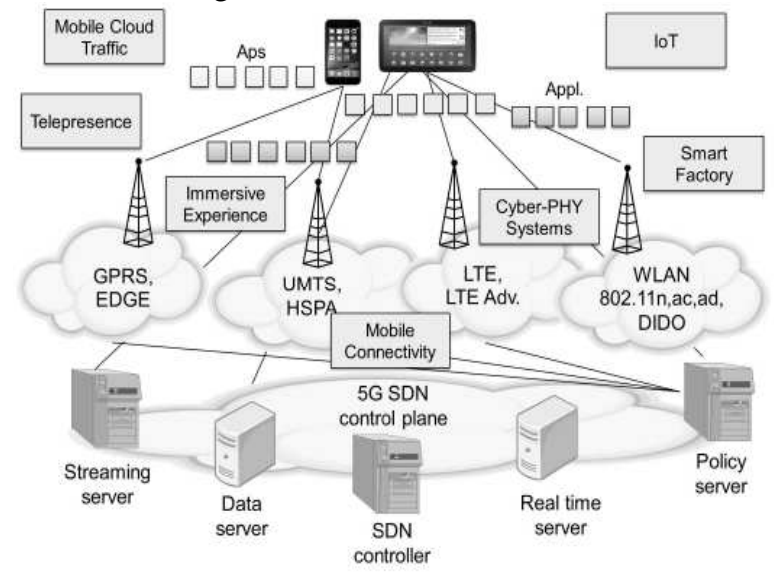

Legend: SDN - Software-Defined Networking; IoT-Internet of Things

Fig. 1. Architecture components of 5G Mobile Network

\section{G Inter-Operability to Networks Technologies}

Fig. 2 compares 5G/IMT2020 networks and their predecessors with WLAN protocols which can provide mutual inter-operability. The following WLAN technologies have to provide inter-operability to $5 \mathrm{G}$, i.a.:

- IEEE 802.11ac (2013)

o larger channel bandwidths up to $160 \mathrm{MHz}$ and optimized modulation, 8x8 MIMO overseen

○ $\max . \mathrm{DR}=6936 \mathrm{MBit} / \mathrm{s}$.

○ nowadays only $3 \times 3 \mathrm{MIMO}, \mathrm{BW}=80 \mathrm{MHz}$, $\mathrm{DR}=1299 \mathrm{MBit} / \mathrm{s}$ on the market.

\section{- IEEE 802.11ad}

- In contrast to traditional WLAN is only for a few meters; this results from the high absorption of oxygen at $60 \mathrm{GHz}$.

- A large $\mathrm{BW}$ to the higher $\mathrm{DR}=7 \mathrm{GBit} / \mathrm{s}$. $\circ$ The $60 \mathrm{GHz}$ band is from 57 to $66 \mathrm{GHz}$, and is divided by a channel spacing of 2160 $\mathrm{MHz}$ in four channels having a bandwidth of $1760 \mathrm{MHz}$.

- IEEE 1905

- Standard which defines a network enabler for home networking supporting both wireless and wireline technologies: IEEE 802.11 (Wi-Fi), IEEE 1901 (HomePlug, HD-PLC) powerline networking, IEEE 802.3 Ethernet and Multimedia over Coax (MoCA).

○ 2010: Group 1905.1 started, development of convergence digital home network specifications, around 30 organizations participated.

○ 2013: draft P1905.1 with final approval and publication by IEEE.

- Piconets: WSN, Bluetooth, 6LoWPAN.

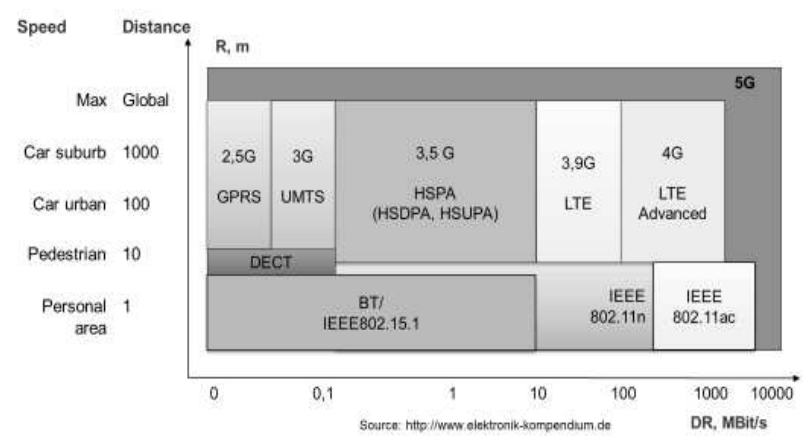

Fig. 2. Overall comparison of distances and data rates for wireless and telecommunication networks (source: www.elektronik-kompendium.de)

\section{Distributed Input - Distributed Output}

DIDO (Distributed Input Distributed Output) must be a part of $5 \mathrm{G}$ as a new resource allocation method for future WLANs by opinion of Rearden (USA) $[15,16]$.

DIDO - a new technology aimed to provide flexible multiuser wireless LAN everywhere under international voting and conventions for the used frequencies $[15,16]$ amongst other mobile technologies towards 5G. DIDO is aimed to resource allocation for future wireless communication networks which can use the wide nontraditional frequencies spectra between $3 \mathrm{MHz}$ and 30 $\mathrm{GHz}$ and independently with full bandwidth and data rate operate under the distances between $100 \mathrm{~m}$ and $1000 \mathrm{~km}$. But the technology should only augment the existing GERAN, UTRAN, SAE and IMS mobile radio infrastructure [6 - 10] of previous generations 2G-4G with a flexible world-wide WLAN, which is operated 
under use of a data bases for available frequency bands and the Web-based content called DIDO Data Centers.

The use of wide spectrum of frequencies is thus foreseen $[15,16]$ on the different distances $100 \mathrm{~m} \ldots 1000$ $\mathrm{km}[1,3,15,16]$. The pioneer of DIDO approach is Rearden Company (USA). Nowadays DIDO (US-Patent) is one of the most important research fields on 5G. Primarily DIDO was tested by some frequencies $F=1$ $\mathrm{MHz} \ldots 1 \mathrm{GHz}$ in WLAN-mode. But in mid-term DIDO has to use all these wave lengths $(\lambda)$ and frequency bands (F) which are given below respectively $[15,16]$ :

- HF - High Frequency $(100 \mathrm{~m} / 3 \mathrm{MHz}-10 \mathrm{~m} / 30$ $\mathrm{MHz}$;

- UHF - Ultra High Frequency $(1 \mathrm{~m} / 300 \mathrm{MHz}-$ $1 \mathrm{dm} / 3 \mathrm{GHz}$;

- $\mathrm{SHF}$ - Super High Frequency $(1 \mathrm{dm} / 3 \mathrm{GHz}-1$ $\mathrm{cm} / 30 \mathrm{GHz}$ );

- EHF - Extremely High Frequency $(1 \mathrm{~cm} / 30 \mathrm{GHz}$ $-1 \mathrm{~mm} / 300 \mathrm{GHz}$ ).

The DIDO advantages are depicted in Fig.3.

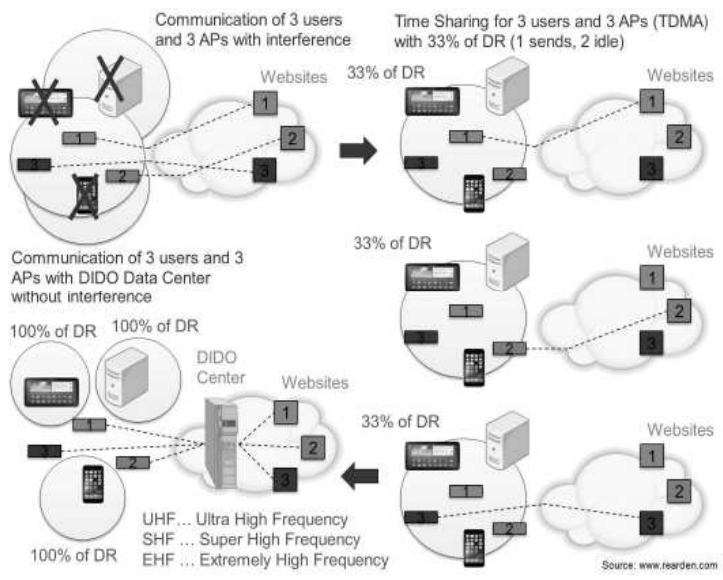

Legend: $D R$ - data rate

Fig. 3. DIDO Advantages by Rearden [15, 16]

The communication of 3 users and 3 depicted APs can follows only with interference. Therefore, Time Sharing for 3 users and 3 APs (TDMA) with 33\% of DR (1 sends, 2 idle) respectively is necessary. Under use of future DIDO for the communication of 3 users and 3 APs a DIDO Data Center is provided. The users and APs can be operated without interference and with full bandwidth. The process with $5 \ldots 10$ users and $5 \ldots 10 \mathrm{APs}$, connecting to $5 \ldots 10$ different websites is shown. There is no interference among the $5 \ldots 10$ users, and all users get the benefit of $100 \%$ of the data rate of the channel, and it doesn't matter where the APs are located or which user owns which. Each user gets the data from the website they are connected to through an independent wireless channel $[15,16]$. The single disadvantage of DIDO is the necessity of inter-governmental agreements and certain regulatory bodies to use the wide spectra of frequencies! Instead of time sharing we obtain 3 independent WWWsessions. DIDO architecture is depicted in Fig. 4.

DIDO has also certain specifics on rural areas because of have to operate with lower frequencies, i.e. HF-band $(100 \mathrm{~m} / 3 \mathrm{MHz}-10 \mathrm{~m} / 30 \mathrm{MHz})$ and reflected waves via large distances (approx. $900 \mathrm{~km}$ ). DIDO Rural is depicted in Fig. 5. DIDO APs on rural areas are able to transmit far longer distances than regular WLAN APs or cellular towers. The transmission can be provided via the wellknown "Sky Waves" (Near-Vertical Incidence Sky Waves, NVIS). They cannot be blocked by the curvature of the Earth and can cover the diameter approx. $900 \mathrm{~km}$ ! NVIS are the alternative of the ground waves (GWaves) transmissions which can cover about $\mathrm{d}=70 \mathrm{~km}$ in diameter before being blocked by the curvature of the Earth $[15,16]$.

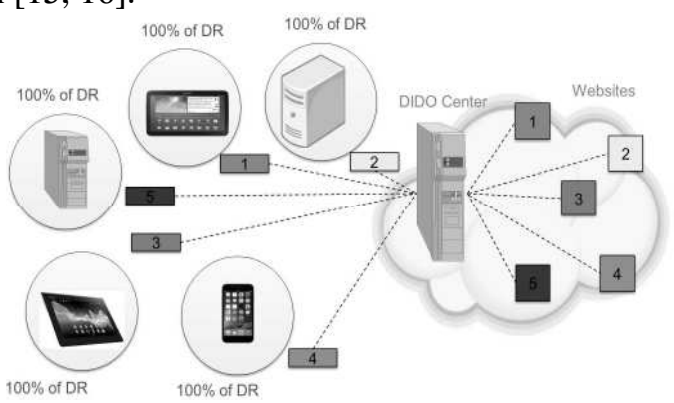

Legend: DR - data rate, the components are as follows: DIDO user devices (Tablets, Smartphones, Notebooks, PC); DIDO AP (5G/WLAN); DIDO Data Centers (Cloud Wireless)

Fig. 4. DIDO Architecture by Rearden [15, 16]

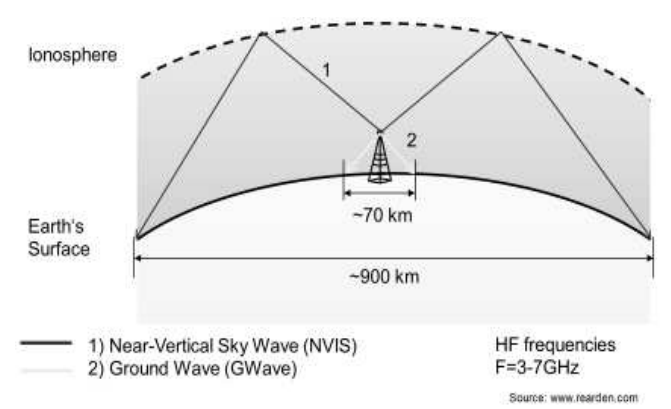

Fig. 5. DIDO Rural by Rearden $[15,16]$

\section{Conclusions}

1. DIDO method is aimed to provide flexible multiuser wireless LAN everywhere under international voting and conventions for the used frequencies. The technology will augment the existing GERAN, UTRAN, SAE and IMS, i.e. previous generations $2 \mathrm{G}-4 \mathrm{G}$ with a flexible 
world-wide WLAN, which is operated under use of special databases called DIDO Data Centers.

2. The single disadvantage of DIDO is the necessity of inter-governmental agreements and certain regulatory bodies to use the wide spectra of frequencies!

3. But just have the $5 \mathrm{G}$ nets to become a totally WLAN that create a totally WLAN infrastructure that creates necessary conditions for higher data rates, QoS and QoE, as well as intelligence for IoT (Internet of Things)? There are no answers yet.

\section{Acknowledgment}

All my graceful heart's acknowledgements to Dr. J.Spillner with ZHAW (Switzerland) and Prof.L.Globa with NTUU-KPI Kyiv (Ukraine), Mr.H.Benn with Samsung and many other colleagues for their helpful and friendly support, the inspirations and co-operation in meaning construction while completing this work.

\section{REFERENCES}

[1] 5G-Laboratory@TUDresden (Online): http://5glab.de/

[2] Frank Fitzek. 5G Next Generation Mobile Communication. In Proceedings of International Symposium on Microwave and Optical Technology (ISMOT), Dresden, June 2015.

[3] Howard Benn. 5G Mobile Communications for 2020 and Beyond: Vision and Key Enabling Technologies, Samsung, Oct. 2014.
[4] 5G Nanocore (Online, in German): http://de.scribd.com/doc/87616878/5G-the-Nano-Core

[5] NanoZEIT@TUD (Online, in German): http://www.et.tudresden.de/etit/index.php?id=556

[6] A.Luntovskyy, D.Guetter, I. Melnyk. Planung und Optimierung von Rechnernetzen: Methoden, Modelle, Tools für Entwurf, Diagnose und Management im Lebenszyklus von drahtgebundenen und drahtlosen Rechnernetzen. Springer/Vieweg + Teubner Verlag Wiesbaden, 2011, 411 p. ( in German).

[7] A.Luntovskyy et al. Distributed Services for Telco Networks: Ubiquitous Computing and Cloud Technologies, Monograph, Lvivska Politechnika, Lviv, 2012, 368 p. (ISBN 978-966-2405-87-3, in Ukrainian).

[8] A.Luntovskyy et al. Multiservice Mobile Platforms, Monograph, DUT State Univ. of Telco, Kyiv, 2014. - 216 p. (ISBN 978-977-2105-89-3, in Ukrainian).

[9] A.Luntovskyy et al. Data Security in Distributed Systems, Monograph, Lvivska Politechnika, Lviv, 2014. - 464 p. (ISBN 978-966-322-397-1, in Ukrainian).

[10] A.Luntovskyy et al. New Architectures in Distr. Systems, Monograph, Kolo, Lviv-Drogobych, 2015. - 328 p. (ISBN: 978-617-642-185-6, in Ukrainian).

[11] T. Thieme. Challenges of the Internet of Things for sensor applications, wireless communication and new solutions of energy supply. In Proceedings of International Symposium on Microwave and Optical Technology (ISMOT-2015), Dresden, June 2015.

[12] Jennic Wireless Microcontrollers (Online): http://www.jennic.com/

[13] J.Brien. WLAN for everybody: MS plans a world-wide WiFi-Net for the Office clients, June 2015 (in German).

[14] S. Hong et al. FQAM: A modulation scheme for beyond 4G cellular wireless communication, Samsung Electronics, in Globecom Workshops, 2013 IEEE.

[15] Steve Perlman et al. Distributed-Input-Distributed-Output Wireless Technology: A New Approach to Multiuser Wireless, Whitepaper, Rearden.com, 2014, 19p.

[16] Steve Perlman, Antonio Forenza. Introduction to pCell - Wireless Reinvented, Artemis Networks LLC, Whitepaper, 2015, 99 p.

Received in final form on November 24, 2016

\section{Лунтовський А.О., Климаш М.М.}

\section{Новий підхід до розташування ресурсів для майбутніх безпроводових локальних мереж}

Проблематика. Сьогодні мобільний зв'язок зайнятий наданням IP-сервісів та передаванням мультимедійного контенту з одного місця в інше, але вже завтра нове покоління 5G зможе контролювати широкий спектр матеріальних об'єктів у реальному часі із лише незначним втручанням людини. Створюється так званий Інтернет речей «ІоТ» із безліччю нових привабливих програм. У поданій роботі розглянутий новий підхід до розподілу ресурсів для майбутніх безпроводових локальних мереж у складі мереж 5G.

Мета досліджень. DIDO (Distributed Input Distributed Output) - нова технологія, яка направлена на надання послуг гнучкої багатокористувацької безпроводової мережі в усьому світі у межах міжнародного узгодження і конвенцій для використовуваних частот серед інших мобільних технологій для інтеграції з 5G. Техніка DIDO націлена на розподіл ресурсів для майбутніх мереж безпроводового зв'язку, які можуть використовувати широкий спектр «нетрадиційних» частот від 3 МГц до 30 ГГц і працювати незалежно одна від одної із повною пропускною спроможністю і високою швидкістю передачі даних на відстанях від 100 м до 1000 км.

Методика реалізації. Був проведений аналіз усіх відомих публикацій, які присвячені новому поколінню мобільного зв'язку 5G. Досліджувались аспекти взаємодії 5G із WLAN, BT, WSN та іншими мікро- и пікорадіомережами. Розглянутий новий підхід до розподілу частотних ресурсів для майбутньої WLAN.

Результати досліджень. Представлений огляд, а також обговорюються основні напрямки розробки майбутніх мереж мобільного радіозв'язку 5G за стандартом IMT 2020. Вони включають, окрім іншого, перспективну технологію DIDO (Distributed Input Distributed Output) для розподілу ресурсів для майбутніх мереж безпроводового зв'язку. Зазначена технологія повинна тільки розширити існуючу інфраструктуру мобільного радіозв'язку GERAN, UTRAN, SAE i IMS попередніх поколінь 2G - 4G за допомогою гнучкої «всесвітньої» WLAN, яка працює з використанням баз даних для доступних діапазонів частот та з доступом до Web-контенту на основі так званих DIDO-центрів (DIDO Data Centers). 
Висновки. Эфективні WLAN, у тому числі із використанням техноології DIDO, повинні стати частиною нових систем покоління 5G. У якості нового метода розподілу ресурсів для майбутніх безпроводових локальних мереж, 3 точки зору деяких провідних компаній, таких як Rearden, Microsoft, Samsung, Huawei, має бути використаний метод DIDO.

Ключові слова: покоління мобільного зв'язку 5G; безпроводова локальна мережа WLAN; метод розташування ресурсів DIDO; Інтернет речей «IoT»; якість обслуговування QoS; визнана якість обслуговування QoE (Quality of Experience).

\section{Лунтовский А.О., Климаш М.М.}

\section{Новый подход к размешению ресурсов для будущих беспроводных локальных сетей}

Проблематика. В настоящее время мобильная связь занята предоставлением IP-сервисов и передачей мультимедийного контента из одного места в другое, но уже завтра новое поколение 5G сможет контролировать широкий спектр материальных объектов в реальном времени с только незначительным вмешательством человека. Создается так называемый Интернет вещей «ІоТ» с множеством новых привлекательных приложений. В данной работе рассматривается новый подход к распределению ресурсов для будущих беспроводных локальных сетей в составе сетей $5 \mathrm{G}$.

Цель исследований. DIDO (Distributed Input Distributed Output) - новая технология, направленная на предоставление услуг гибкой многопользовательской беспроводной сети во всем мире в рамках международного согласования и конвенций для используемых частот среди других мобильных технологий для интеграции с 5G. Техника DIDO нацелена на распределение ресурсов для будущих сетей беспроводной связи, которые могут использовать широкий спектр «нетрадиционных» частот от 3 МГц до 30 ГГц и работать независимо друг от друга с полной пропускной способностью и высокой скоростью передачи данных на расстояниях от 100 м до 1000 км.

Методика реализации. Был проведен анализ всех известных публикаций, посвященных новому поколению мобильной связи 5G. Исследованы аспекты взаимодействия 5G с WLAN, BT, WSN и другими микро- и пикорадиосетями. Был рассмотрен новый подход к распределению частотных ресурсов для будущей WLAN.

Результаты исследований. Представлен обзор, а также обсуждаются основные направления разработки будущих сетей мобильной радиосвязи $5 \mathrm{G}$ по стандарту IMT 2020. Они включают, помимо прочего, перспективную технологию DIDO (Distributed Input Distributed Output) для распределения ресурсов для будущих сетей беспроводной связи. Указанная технология должна только расширить существующую инфраструктуру мобильной радиосвязи GERAN, UTRAN, SAE и IMS предыдущих поколений $2 \mathrm{G}$ - 4G с помощью гибкой «всемирной» WLAN, которая работает с использованием баз данных для доступных диапазонов частот и с доступом к Web-контенту на основе так называемых DIDO-центров (DIDO Data Centers).

Выводы. Эффективные WLAN, в том числе с использованием техноологии DIDO, должны стать частью новых систем поколения 5G. В качестве нового метода распределения ресурсов для будущих беспроводных локальных сетей, по мнению некоторых ведущих компаний, таких как Rearden, Microsoft, Samsung, Huawei, должен использоваться метод DIDO.

Ключевые слова: поколение мобильной связи 5G; беспроводная локальная сеть WLAN; метод размещения ресурсов DIDO; Интернет вещей «IoT»; качество обслуживания QoS; признанное качество обслуживания QoE (Quality of Experience). 